\title{
ЗНАЧЕННЯ ЕТИКО-ДЕОНТОЛОГІЧНИХ АСПЕКТІВ В УПРАВЛІННІ ЯКІСТЮ РОБОТИ МЕДСЕСТРИНСЬКОЇ СЛУЖБИ
}

\author{
Н. Б. Галапац, О. Н. Литвинова \\ Жовківська центральна районна лікарня Львівської області \\ ДВНЗ «Тернопільський державний медичний університет імені І. Я. Горбачевського \\ МОЗ України»
}

Вплив особистості медичного працівника на психіку хворого та на результат захворювання значний, особливо в умовах розвитку демократичного суспільства. Тому довіряючи медичному працівникові найдорожче, що є в людини, - життя і здоров'я, люди повинні бути твердо впевнені в тому, що їм допомагають добрі, надійні й теплі руки.

Чесне ім'я й авторитет медичних працівників кожного медичного закладу - авторитет усіеї медицини.

\section{SIGNIFICANCE OF ETHICAL AND DEONTOLOGICAL ASPECTS IN QUALITY MANAGEMENT OF NURSING SERVICE}

\author{
N. B. Halapats, O. N. Lytvynova \\ Zhovkva Central Regional Hospital of Lviv Region \\ SHEI «Ternopil State Medical University by I. Ya. Horbachevsky of MPH of Ukraine»
}

The influence of a health care worker on a psyche of a sick person as well as on the disease outcome is tremendous in the conditions of democratic society development. Therefore entrusting of health care worker the most important to a human being - life and health, people ought to firmly believe that those hands that help them are kind and warm.

Honest name and standing of health care workers in every health facility are the authority of the medical industry in general.

Вступ. Медицина в сучасному світі відіграе особливу роль у житті людини і суспільства. Відносини між лікарем, медсестрою і пацієнтом вимагають від медичних працівників професійних знань, належної правової бази у галузі охорони здоров'я, а особливо дотримання моральноетичних норм.

Медична етика є конкретизацією загальних принципів моралі стосовно професії медичного працівника. Вона $є$ нормою поведінки медичної сестри не лише під час виконання службових обов'язків, вона виражае ії професійну честь i гідність.

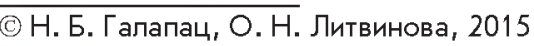

Основними положеннями етики є:

1) повага до життя;

2) заборона на заподіяння шкоди хворому;

3) повага до особистості хворого;

4) лікарська таємниця;

5) повага до професії.

Медична деонтологія є частиною медичної етики - це норми поведінки медичних працівників, які зобов'язують їх підвищувати якість лікування й усувати наслідки неповноцінної медичної роботи.

Провести чітку межу між моральними та правовими нормами нерідко дуже складно, особливо в наш час. Однак нерідко моральні норми, 
обов'язки стають юридичними, правовими (наприклад, клятва медичного працівника).

Медична етика, медична деонтологія і правова культура тісно пов'язані мік собою. Вони виражають систему норм права і моралі та взаємодіють у процесі регулювання конкретних суспільних і медичних відносин.

Правова культура медичного працівника це його правосвідомість, розуміння принципів медичного права, повага до нього, переконаність у справедливості законів та в потребі їх неухильного дотримання у медичній діяльності. Це критичне творче осмислення правових норм, законів, правових явищ 3 погляду їх гуманістичного, демократичного і морального змісту.

Мораль та правова відповідальність мають різний характер. Якщо право стосовно людини сила зовнішнього примусу, то моральний аспект це відповідальність не тільки перед іншими, а й перед самим собою, перед своєю совістю.

Особливо актуальними питання етики та деонтології постають сьогодні у час, коли в Україні повним ходом йде неоголошена війна і сотням пораненим молодим воїнам разом 3 медикаментозною терапією необхідне лагідне слово, підтримка і душевна теплота медичного персоналу. Левова частка догляду цих хлопців лягає на плечі саме середнього медичного персоналу.

Основна частина. Світова громадськість в усі часи надавала морально-етичному аспекту в медицині великого значення. Видатні представники медичної професії завжди наголошували на гуманній сутності медицини, закликали до милосердя, чесного й самовідданого виконання медиками своїх професійних обов'язків за покликанням та по совісті.

У XX ст. сестринська діяльність сформувалась як самостійна професія 3 власними функціональними обов'язками, методами та засобами їх виконання, які були закладені ще Флоренс Найтінгейл у сестринській клятві. Ці функції вимагають конкретизації загальних моральних принципів і цінностей відповідно до умов праці медичних сестер.

Медсестра, яка починає працювати, керуючись моральними нормами поведінки, зобов'язується поліпшувати, підтримувати та відновлювати здоров'я, полегшувати страждання пацієнтів та запобігати хворобам. Як громадянин медсестра має дотримуватись моральних та законних норм, які поділяють усі члени суспільства. Як особистість вона має право вибирати спосіб життя відповідно до власних етичних цінностей, особистої етики, але доти, доки ці цінності не шкодитимуть паціентам.
Медсестри в клінічній практиці, освіті, адмініструванні та дослідженні поділяють загальні погляди щодо отримання компетентної медичної допомоги та поліпшення практики догляду за хворими. Взаємовідносини медичної сестри і паціента є головним складником проблем медичної етики і деонтології. Цим пояснюється специфіка діяльності медичних працівників, адже хворий добровільно довіряе їм свое здоров'я та розкриває всі сторони свого життя.

У Стандартах акредитації закладів охорони здоров'я України у розділі 4 «рава, обов'язки та безпека пацієнтів» включено такі питання 3 медичної етики та деонтології, які необхідно виконувати у всіх структурних підрозділах закладів охорони здоров'я:

1) проведення семінарських занять 3 медичним персоналом закладу з питань дотримання етики та деонтології;

2) проведення заходів щодо попередження зловживань працівниками закладу;

3) здійснення контролю за дотриманням медичним персоналом принципів етики та деонтології;

4) проведення занять 3 медичним персоналом щодо дотримання конфіденційності інформації про паціента;

5) дотримання медичним персоналом принципу конфіденційності інформації.

Враховуючи важливу роль морально-етичних принципів, норм і цінностей у безпосередньому виконанні медичними сестрами своїх професійних обов'язків, вагоме значення етичних норм у стандартах якості роботи медичних сестер, а також гуманну функцію етичних норм у вирішенні проблем, пов'язаних із впровадженням сучасних наукових технологій у медсестринську практику, введено в дію Етичний Кодекс медичної сестри України.

Наведу декілька основних частин Кодексу.

\section{Частина 1. Загальні положення.}

У житті і діяльності медичної сестри органічно поєднуються: високий професіоналізм, гуманність та милосердя, глибоке поняття громадського значення своеї роботи, комплексний всебічний догляд за пацієнтами і полегшення їх страждань, відновлення здоров'я і реабілітація, сприяння зміцненню здоров'я і попередженню захворювань, готовність цілком віддати себе обраній професії, навіть в самих тяжких умовах. Етичний Кодекс висвітлюе моральний рівень медичної сестри, її світогляд, покликаний підвищувати престиж і авторитет сестринської професії в суспільстві, сприяти розвитку сестринської справи в Україні. 
Частина 2. Медична сестра і її пацієнт.

Стаття 1. Медична сестра як особистість.

Особистість медичної сестри - це органічний сплав високих моральних якостей, загальної освіченості, професійної ерудиції та майстерності. Медична сестра оберігає людське життя, починаючи з зачаття і ніколи, навіть під загрозою, не повинна використовувати медичні знання в збиток нормам гуманності.

Етичною основою медичної сестри є гуманізм та милосердя, повага до невід'ємних прав людини і громадянина. Відновлення і покращення здоров'я пацієнта є для медсестри найвищою винагородою за її працю.

Етичний Кодекс Міжнародної ради медсестер

Етичні основи медсестринської справи.

На медсестру покладено чотири основні обов'язки: зберігати здоров'я, запобігати захворюванням, відновлювати здоров'я і полегшувати страждання.

Робота медсестри універсальна. Медсестринська справа ґрунтується на повазі до життя, гідності й прав людини. Вона не має обмежень за національними і расовими ознаками, за ознаками віросповідання, кольору шкіри, віку, статі, політичного або соціального становища.

Медсестри надають медичну допомогу особам, сім'ям і суспільству, координують свою діяльність із роботою інших груп.

Медичні сестри цілодобово спілкуються 3 хворими, полегшують їх страждання, здійснюють призначене лікарем лікування, повертають працездатність.

\section{Медсестра іпаціенти}

Основну відповідальність сестра несе перед тими, хто потребує ї̈ допомоги. Надаючи допомогу, медсестра намагаеться створити атмосферу шанобливого ставлення до етичних цінностей, звичаїв і духовних переконань паціента. Медсестра зберігає одержану конфіденційну особисту інформацію і ділиться нею з надзвичайною обережністю.

Медична сестра повинна пам'ятати, що ї зовнішність має великий вплив на одужання хворого. Вона повинна бути взірцем чистоти та акуратності. Ії робочим одягом є халат, шапочка або косинка, тапочки. Білий халат - це своєрідна "візитна картка" медичної сестри, що відображає ії фізичну й духовну чистоту. $€$ чудовий вислів фронтового лікаря Павла Бейліна про зовнішній вигляд медичної сестри: «Сестру я визначаю по тому, який у неї халат, - чистий, випрасуваний, накрохмалений, застібнутий на всі ґудзики, значить, такій медичній сестрі можна довіритись. Значить пишається своєю професіею, халат одягає, як казкова королева мантію».
Медична сестра повинна стати ключовою фігурою у профілактиці захворювань та просвіті населення щодо здорового способу життя.

Отже, можна виділити такі риси медичної сестри:

- моральні риси - стриманість, терпеливість, ввічливість, привітність, чесність, ніжність, ласкавість, співчуття і почуття власної гідності;

- етичні риси - скромність, простота, акуратність, уміння створити затишну атмосферу;

- інтелектуальні риси - професійна ерудиція, спостережливість, вміння логічно мислити.

Поведінка медичної сестри повинна викликати повагу до неї, довіру, створювати у хворих впевненість, що вона все знає і все уміе, що їй можна довіряти своє здоров'я і життя. Жодні особисті неприемності не повинні «відбиватися» на їі роботі, в їі тоні при розмовах із колегами та хворими.

П. Бейлін у книзі «Поговори зі мною, лікарю» так пише про значення слова: «... слово такою ж мірою ефективне у роботі медичної сестри, як і скальпель - у хірургії. Але за однієї умови: якщо володіють ним. Скальпелем доторкаються до тіла, словом до душі. Як не можна користуватися тупим скальпелем, так само не можна користуватися «тупим словом» [2] .

Говорячи про вищезгадані риси не можна не згадати про «Маленьку велику жінку» так назвав іï Папа Іван Павло II - це Мати Тереза.

Усе своє довге і великодушне життя вона присвятила найбільш нещасним і незахищеним серед нас - бідним, голодним, невиліковно хворим і вмираючим у самотності та стражданнях. Кожен ранок цієї жінки розпочинався $з$ молитви св. Франциска Асизького: «Господи! Дай мені сили Втішати, а не бути втішеним, Розуміти, а не бути зрозумілим, Любити, а не бути любимим. Бо тільки коли ми віддаємо, ми отримуємо. А прощаючи, знаходимо собі прощення» [3].

Вона любила говорити: «У кожній людині я бачу Христа. А оскільки Христос назавжди один, то для мене в кожний конкретний момент - це той, хто стоїть переді мною, хто потребує моєї допомоги». Лейтмотивом її вчення і подвижництва були слова Христа: «Оскільки ви зробили це одному з братів Моїх, то зробили Мені».

Вона розповідала: «Мене часто запитують: коли зникнуть голод, бідність, хвороби на землі? Відповідь одна - тоді, коли ти і я почнемо ділитися. А щоб полюбити бідного, ми самі повинні стати бідними... Найгірші захворювання сьогодні - не проказа, СНІД або туберкульоз, а швидше, почуття непотрібності та самотності».

Медсестра іпрактика

Медсестра особисто відповідае за виконання своїх обов'язків на практиці і за постійне 
підвищення кваліфікації. Вона намагається виконувати роботу якнайкраще.

Медична сестра приймає виважені рішення про особисту компетенцію, даючи і беручи на себе доручення.

Виконуючи професійні обов'язки, медсестра повинна постійно поводитися так, щоб не підривати довіри до професії. Все це викладено у клятві основоположниці медсестринської справи Флоренс Найтінгейл.

Клятва Флоренс Найтінгейл

«Перед Богом і перед обличчям присутніх, я урочисто обіцяю жити життям, наповненим чистотою, і чесно виконувати свої обов'язки.

Я буду стримуватися від всього ядовитого і поганого і ніколи свідомо не використаю і не призначу медикаменти, які можуть спричинити шкоду.

Я зроблю все, що в моїй силі, щоб підтримувати і підвищувати рівень моєї професії. Я буду зберігати в таємниці всю особисту інформацію, яка буде в моєму розпорядженні під час роботи з пацієнтами та їх родичами.

Я буду віддано допомагати лікарю в його роботі і присвячу себе невтомному піклуванню про благополуччя всіх доручених мені.

Клянуся! Клянуся! Клянуся!» [4].

Медсестра і співробітники

Медсестра підтримує взаємини співробітництва $з$ іншими медичними медсестрами і $з$ тими, з ким їй доводиться працювати.

Медсестра вживає необхідних заходів для безпеки пацієнта, якщо його стану загрожує небезпека зі сторони співробітників або інших людей [4].

Колегіальність у медицині - це не тільки дотримання відповідних етичних норм, а своєрідне колективне надбання професійного досвіду; це школа, де набувають медичної майстерності через інформацію, що передається вербальним шляхом за максимально короткий проміжок часу.

Психологічний клімат у медичному колективі - не просто сукупність особистих якостей його співробітників. Він утворюється внаслідок взаємин між членами колективу. Джерелом складних взаємин у деяких медичних колективах часто є відсутність творчої роботи по спрямуванню зусиль його членів на виконання основного завдання - боротьби за здоров'я хворого. Висока культура медсестер передбачає вимогливість кожної медсестри до себе, вміння тактовно та у доброзичливій формі звернути увагу своїх колег на їхні недоліки в роботі, а також вміння сприйняти зауваження щодо своєї особи. Самовпевненість і зарозумілість у роботі медичних працівників неприпустимі, і в інтересах хворого треба виявляти максимум такту і самодисципліни. Усі ці складові регулюються нормами професійної етики медичного працівника [5].

Найважливіші міжособистісні стосунки медичних сестер у колективі:

- медична сестра - керівництво медичного закладу;

- медична сестра - лікар;

- медична сестра - середній та молодший медичний персонал;

- медична сестра - паціент та його родичі або відвідувачі.

Принципи взаємодії «лікар - медсестра»:

- принцип розмежування функцій;

- принцип чіткого функціонального обмеження;

- принцип партнерства.

У взаємовідносинах медсестри з пацієнтами, колегами, лікарями та іншим медичним персоналом не без виникнення конфліктів та їх наслідків. Проява їх має різну ступінь та різні прояви, як зокрема:

Медична сестра - пацієнт (представник паціента, відвідувач тощо):

- псування міжособистісних стосунків;

- погіршення стану здоров'я або смерть пацієнта, що може стати причиною судового розгляду конфлікту та виплати компенсації;

- псування ділової репутації медичного закладу;

- розголошення відомостей про конфлікт у ЗМl;

- зменшення кількості пацієнтів та прибутків медичного закладу;

зменшення додаткових матеріальних винагород (премій).

Медична сестра - лікар:

- псування міжособистісних стосунків, зниження рівня довіри;

- псування ділової репутації медичного закладу (у разі публічності конфлікту);

- ймовірність додаткових перевірок якості виконання професійних обов'язків з боку керівництва.

Медична сестра-керівник - медична сестрапідлегла:

- псування міжособистісних стосунків, зниження рівня довіри;

- псування ділової репутації медичного закладу (у разі публічності конфлікту);

- ймовірне зменшення додаткових матеріальних винагород (у разі обов'язкового попереднього подання відповідних доповідних записок медичною сестрою-керівником);

- ймовірність додаткових перевірок якості виконання професійних обов'язків з боку керівництва; 
- створення неприйнятних робочих умов та ймовірність кадрових змін.

Медична сестра - медична сестра або молодший медичний персонал:

- псування міжособистісних стосунків, зниження рівня довіри;

- псування ділової репутації медичного закладу (у разі публічності конфлікту).

Медична сестра-керівник - лікар-керівник:

- псування міжособистісних стосунків, зниження рівня довіри;

- погіршення роботи медичного закладу взагалі або його окремих структурних підрозділів;

- погана скоординованість дій старшого та середнього і молодшого медичного персоналу;

- зниження якості медичної допомоги / медичних послуг;

- створення неприйнятних робочих умов та ймовірність кадрових змін.

Запобігання міжособистісним конфліктам полягає в наступному:

- виховання внутрішньої культури середнього та молодшого медичного персоналу (колективне та індивідуальне), у тому числі донесенням до свідомості правил корпоративної етики;

- побудова взаємовідносин із дотриманням субординації та взаємоповаги;

- створення сприятливого робочого мікроклімату;

- ввічливе ставлення до всіх співробітників незалежно від рангу;

- винесення заохочення перед колективом, а стягнень чи доган - в індивідуальному порядку;

- об'єктивний розгляд скарг та претензій, проведення внутрішнього розслідування;

- залучення психолога у разі неможливості вирішити міжособистісний конфлікт самотужки;

\section{ЛITEPATУРA}

1. Малый энциклопедический словарь Брокгауза и Ефрона. - Петербург : Издательское общество «Ф. А. Брокгауз - И. А. Ефрон», 1907-1909 (в современной орфографии).

2. Бейлін П. Ю. Твори : в 2 т. / П. Ю. Бейлін ; худ. В. В. Рудченко. - Т. 2 : Рік щастя. Поговори зі мною лікарю. - К. : Дніпро, 1985. - 488 с.

3. Маленькавеликажінка[Електроннийресурс] / Клара Ґудзик // Газета «День». - Режим доступу : http:// www.day.kiev.ua/uk/article/cuspilstvo/malenka-velikazhinka
- організація корпоративних заходів.

Нові технології в охороні здоров'я, нові методи діагностики і лікування, зростаючі вимоги до рівня медсестринської опіки вимагають високого ступеня компетентності і кваліфікації медичної сестри.

Медсестра, як і інші громадяни, відповідає за здійснення і підтримку заходів, спрямованих на задоволення громадських запитів у галузі охорони здоров'я.

Сучасна медична сестра - це висококваліфікований спеціаліст, професіонал, людина 3 широким світоглядом, яка добре оріентуеться не тільки в своїй професії, але і в проблемах охорони здоров'я і соціальній сфері в цілому [6].

Професію медичної сестри вже давно розглядають як одну 3 ключових професій, тому медсестра - це унікальна, суспільно активна особистість, яка вдосконалює свої професійні, психологічні якості з метою забезпечення оптимального догляду за паціентом.

Висновок. Етико-деонтологічні принципи повинні бути фундаментально покладені в основу поведінки та професійної діяльності медсестри. Вони повинні керуватись міжнародними деклараціями про права людини, Конституцією і Законами України, загальнолюдськими моральними цінностями, принципами і нормами професійної етики та духовним надбанням нашої національної культури.

Високий професіоналізм та майстерність середнього медперсоналу лише в тісному поєднанні з високими моральними засадами дасть позитивні результати в оздоровленні населення України. Без останнього роботу медсестри можна буде вже в найближчому часі замінити високотехнологічними маніпуляторами.
4. Клятва Флоренс Найтінгейл[Електронний ресурс] - Режим доступу : http://www.medcectre.ru/klyatvaflorens-najtingejl/

5. Етичнийкодекс професійноїетики міжнародноїради медсестер [Електронний ресурс]. - Режим доступу : http://medvisnyk.org.ua/content/view/18/9/-Haзва з титул. екрану.

6. Етичний кодекс медичних сестер України, 1999. 